\title{
No. XVIII.-AMPHIPODA GAMMARIDEA FROM THE INDIAN OCEAN, BRITISH EAST AFRICA, AND THE RED SEA.
}

\author{
By Alfred O. WALker, F.L.S., F.Z.S.
}

(Plates $42 \& 43$.

Read 19th March, 1908.

The three collections of Amphipoda treated of in this memoir are as follows:-

I. By Mr. J. Stanley Gardiner, F.L.S., during the voyage of H.M.S. Sealark in 1905.

II. By Mr. C. Crossland at Zanzibar and Wasin, British East Africa, in 1901-2.

III. By the same gentleman in the Red Sea, from October 1904 to May 1905.

The number of species in each collection is as follows :-

I. 32, of which 19 are not in either of the other collections.

II. 23, of which 6 are not in either of the other collections. Of this number 14 were taken at Wasin in mud 10 fath.!

III. 20, of which 6 are not in either of the other collections.

The total number of species in the 3 collections is 50 in 36 genera. Of these 7 are new, viz. :-

$$
\begin{aligned}
& \text { Ichnopus serricrus. } \\
& \text { Stegocephalus globosus. } \\
& \text { Chagosia (g. n.) gardineri. } \\
& \text { Eusiroides diplonyx. } \\
& \text { Lembos leplocheirus. } \\
& \text { Eurystheus monuropus. } \\
& \text { Amphithö̈ lobata. }
\end{aligned}
$$

Another species which I had described under the name of Elasmopus ctenonyx has just been published by $\mathbf{M}$. Chevreux in 'Bulletin du Muséum d'Histoire Naturelle, 1907, No. 6, p. 412, under the name of E. spinidactylus, from the Gambier or Paumotu Archipelago, halfway between Australia and South America. Both names refer to the peculiar comb-like structure of the dactyli of the peræopods.

As regards Geographical Distribution :-

19 species have been found on the Ceylon coasts.

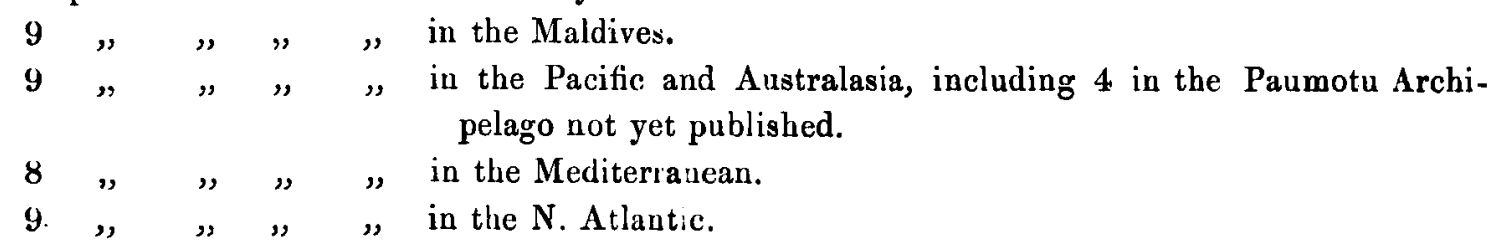


In collection I. only, were species from depths below 100 fathoms, viz. :-

Cyphocaris alicei, Chevreux.

Stegocephalus globosus, sp. n.

Parandania boecki (Stebbing).

Stenopleura atlantica, Stebbing.

Chagosia gardineri, g. \& sp. n.

Eusiropsis riisei, Stebbing.

All of these previously described have hitherto, so far as I know, only been found in the Atlantic.

All necessary references will be found in Mr. T. R. R. Stebbing's "Amphipoda " of "Das 'Tierreich,' a work absolutely indispensable to all workers in this subclass, and a model of careful and accurate arrangement. I have followed this work in the descriptions of species, the basipodite or first free joint being now called the 2 nd joint instead of the 1st as I have hitherto done.

The following species may be mentioned as interesting :-

Colomastix crassinbanus (Heller).

This has generally been united with C. pusillus, Grube, a species not uncommon in sponges on our own coasts, from which $C$. crassimanus is distinguislied by the large hands of the 2nd gnathopods in the adult male. This form has not, so far as I know, been found in this country or anywhere north of the Mediterranean, and appears therefore to be entitled to rank as a distinct species, notwithstanding the similarity of the f'emales.

Eusiropsis riisei, Stebbing.

This species, described and beautifully figured by Mr. Stebbing in the 'Transactions' (2nd ser. Zool. vol. vii.) of this Society, is remarkable for the structure of the last joints of the peræopods, which, instead of the nail-like form usual in the Amphipoda, resemble the 4. preceding joints. The specimen taken by Mr. Gardiner is probably the only one known, besides the two in the Copenhagen Museum from which Mr. Stebbing's description was taken : it is fortunately in perfect preservation.

Chagosia gardineri, g. \& sp. n.

Unfortunately there is only a single specimen of this, which I have assigned provisionally to the fam. Calliopiidæ; it differs, however, from other members of the family in having the 3rd uropods uniramous. The mouth-organs have not been dissected, as to have done so would have destroyed the character of the specimen. 


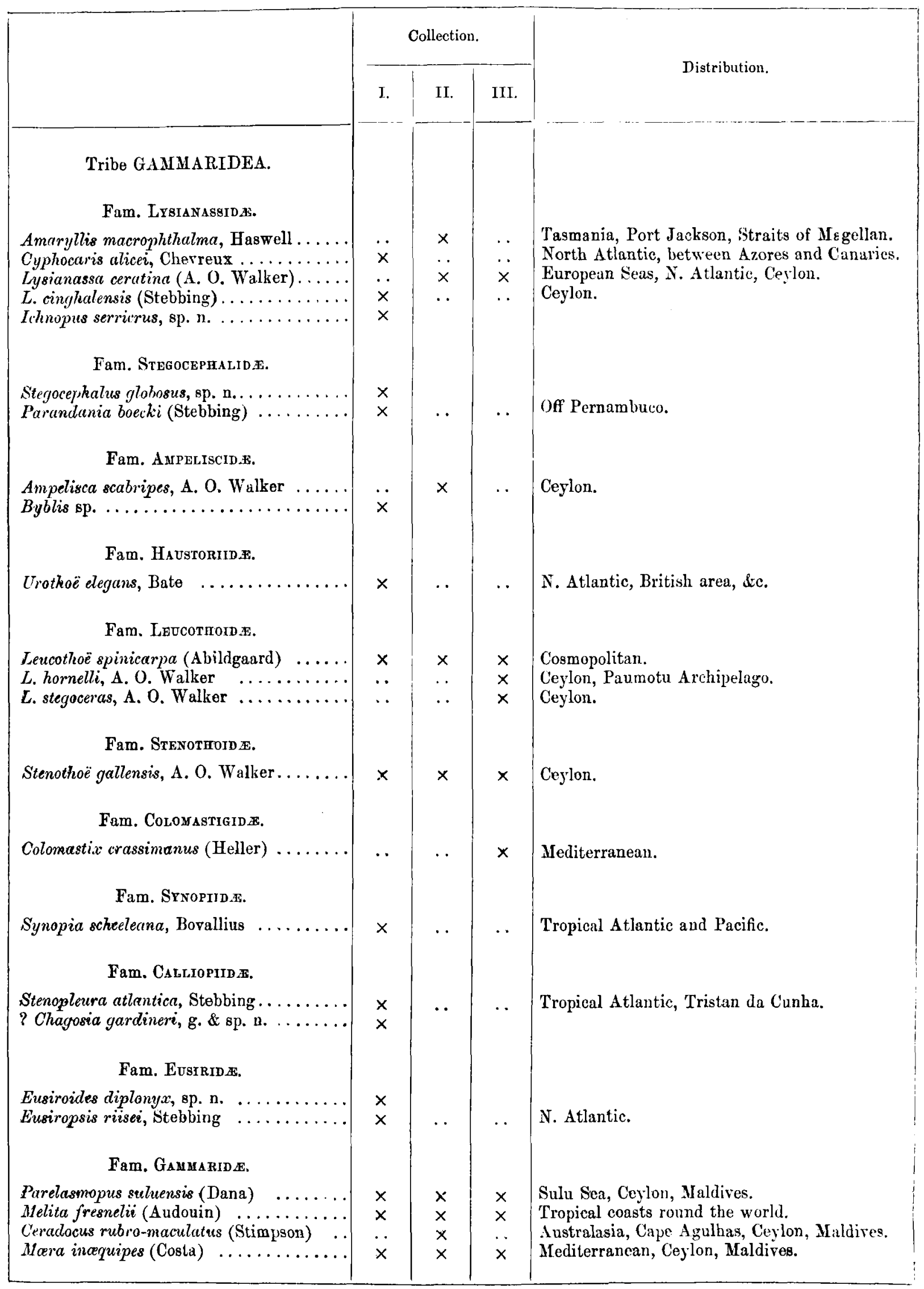




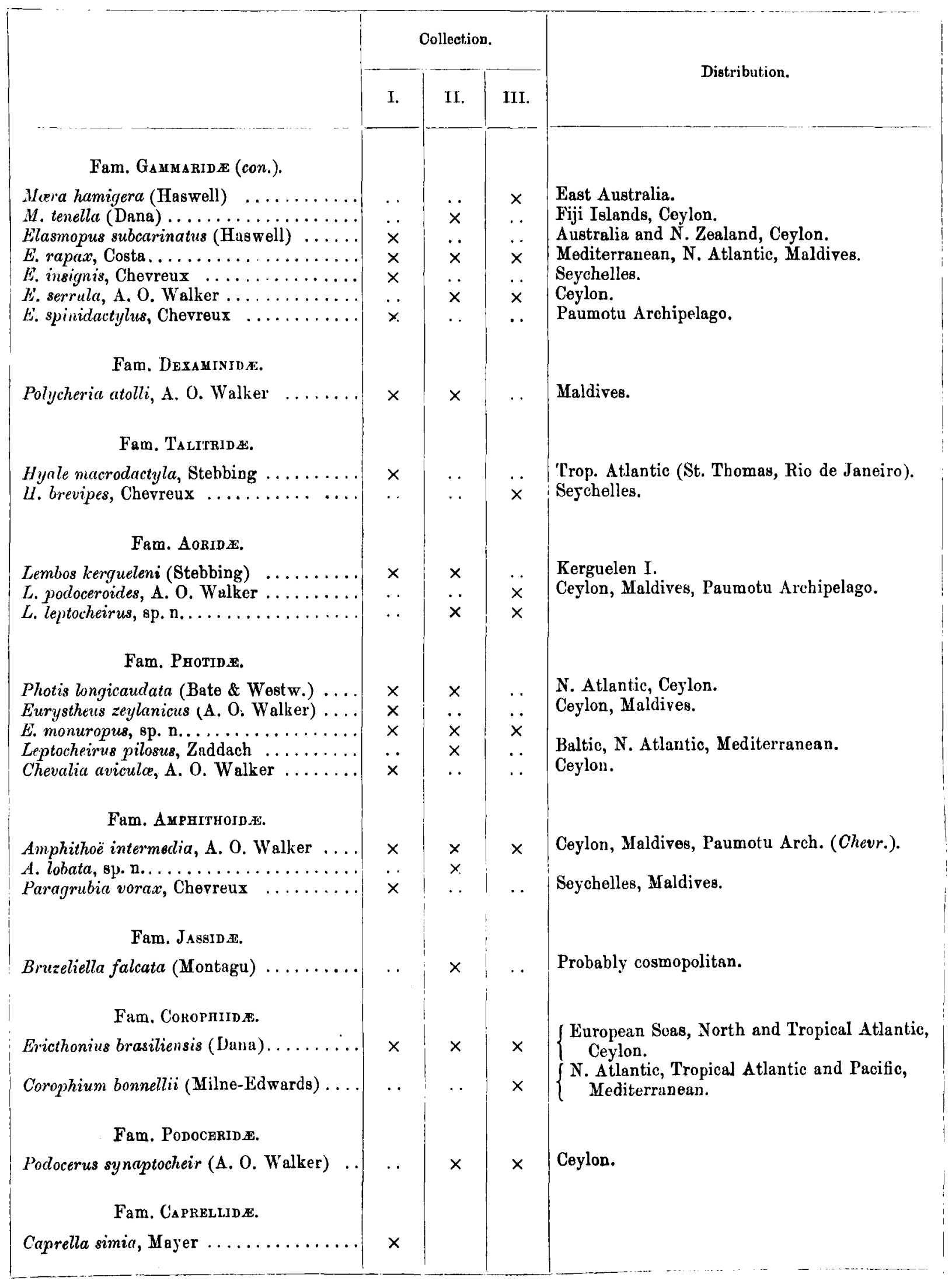


Genus AMAR YLLIS, Haswell, 1880.

1. Amaryllis macrophthalma, Hasw.

II. Wasin, $7 \mathrm{fms}$. and $10 \mathrm{fms}$. (mud). Length of female $9 \mathrm{~mm}$.

Genus CYPHOCARIS, Boeck, 1871.

2. Cyphocaris alicei, Chevreux, 1905.

? Cyphocaris challengeri, Stebbing.

I. N.W. of Desroches Atoll : Plankton, $k k, 300 \mathrm{fms}$., one $3 \mathrm{~mm}$.; $n n, 200 \mathrm{fms}$, many, $15 \mathrm{~mm}$.

M. Chevreux, in comparing his species with C. challengeri, lays stress on the absence in the latter of the hood over the head, formed by the projecting 1st segment, and the presence of teeth on the upper margin of the long process, directed backward, of the 2nd joint of the 3rd peræopods. As regards the former, Chevreux is correct in saying that the young have the hood (which appears to be wanting in C. challengeri), but the teeth on the process are present in the small specimen though not in the large. It is therefore an open question whether these two species are identical or not.

Genus LYSIANASSA, H. M.-Edwards, 1830.

3. Lysianassa ceratina (A. O. Walker).

1887. Lysianassa longicornis, Chevreux, Bull. Soc. Zool. de France, p. 294.

1889. Lysianax ceratinus, A. O. Walker, Proc. Biol. Soc. Liverpool, vol, iii. p. 200, pl. 10.

1893. Lysianax longicornis, Chevr. \& Bouvier, Ann. d. Sci. Nat. p. 111.

1893. Lysianax longicornis, Della Valle, Fauna \&c. Golf. Neapel, Gammarini, p. 790 (part.).

1893. Lysianax bispinosus, Della Valle, Fauna \&c. Golf. Neapel, Gammarini, p. 792.

1895. Lysianax longicornis, A. O. Walker, Trans. Biol. Soc. Liverpool, vol. ix. p. 291.

1896. Lysianax longicornis, A. O. Walker, Rep. Brit. Assoc. p. 438.

1896. Lysianax longicornis, A. O. Walker \& Hornelli, Report on Schizopoda \&c. of the Channel Islands, Journal of Marine Zoology, vol. ii. p. 52.

1897. Lysianax ceratinus, A. O. Walker, Trans. Biol. Soc. Liverpool, vol. xi. pp. 166, 171.

1900. Lysianax ceratinus, Chevreux, Résult. Scient. Campagnes de l'Hirondelle, p. 16, pl. 5. fig. 1.

1900. Lysianax ceratinus, A. M. Norman, Ann. \& Mag. N. H. (7) vol. v. p. 143.

1906. Lysianax ceratinus, A. M. Norman \& T. Scott, Crust. of Devon and Cornwall, p. 56.

1906. Lysianassa longicornis, T. R. R. Stebbing, Das Tierreich, Amphipoda Gammaridea, p. 39 (part.).

II. Wasin, Brit. E. Africa; 10 fms. mud; 3 i , 2 young. Length $7 \cdot 5 \mathrm{~mm}$.

III. Suakim Harbour \&c., 3 or 4.

The above species, which I united with L. longicornis, Lucas, in Ann. \& Mag. Nat. Hist., Feb. 1892, was separated again by Chevreux, who was better acquainted than I with the true $L$. longicornis, in 1900. In addition to the points of difference given by this author, I may mention that, according to Mr. Stebbing (1906, l.c.), in L. longicornis the eyes and flagella of the antennæ are red and the telson apically rounded, while in L. ceratina the eyes are always dark brown or black, the flagella almost colourless, and 
the telson truncate with the angles more or less rounded. In the last respect some specimens approach $L$. cinghalensis, Stebbing, so closely that, not being able to detect any other valid difference, I am compelled to doubt whether this species is distinct. $L$. bispinosa (Della Valle) differs from $L$. ceratina only in the colouring of the integument and (judging from the figure) the number of joints in the accessory flagellum of ant. 1, neither of which characters is of much value. Some of the specimens taken in Ceylon (Amphipoda of Pearl Oyster Fisheries, p. 242), and named L. cinghalensis, doubtless are this species.

'The following synopsis of the species may be useful :-

\section{Synopsis of Lysianassa.}

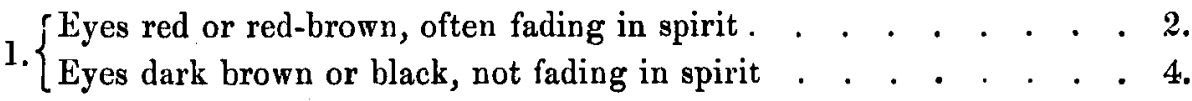

2. Telson squared apically with a cẹtral notch . . . . . . . L. punctata (Costa).

2. $\{$ Telson apically elliptical . . . . . . . . . . . . . . . 3.

Hind angle of pleon segment 3 rounded; a prominent distal tooth

3. on the 1 st joint of ant. 1 . . . . . . . . . . . . . . L. longicornis, Lucas.

Hind angle of pleon segment 3 upturned and acute . . . . . . L. plumosa, Boeck.

Hind angle of pleon segment 3 rounded . . . . . . . . . . 5 .

4. Hind angle of pleon segment 3 upturned . . . . . . . . L. variegata (Stimpson).

Telson apically elliptical . . . . . . . . . . . . . . . 6.

5. $\{$ Telson apically truncate . . . . . . . . . . . . . . . 7 .

6. Palm of 6 th joint of 2 nd gnathopod deeply concave . . . . . . L. colochir (A. O. W.).

6. Palm of 6 th joint of 2nd gnathopod not deeply concave . . . . . L. cinghalensis (Stebb.).

7 Antenna 1: lst joint smooth; inner ramus of 2nd uropod dilated. . L. cubensis (Stebbing).

7. Antenna $1: 1$ st joint with 2 short apical teeth . . . . . . . L. ceratina (A. O. W.).

4. Lysianassa cinghalensis (Stebbing).

I. Amirante I.: Plankton, $g g$, surface. One male $4 \mathrm{~mm}$.

Genus ICHNOPUS, A. Costa, 1853.

5. Ichnopus serricrus, sp. n. (Plate 43. fig. 1.)

I. Amirante: dredged E 10, 22-85 fms.: one ${ }^{*}$. Coco I., Cargados: Plankton, $i$, surface: one $\delta^{*}$.

Head longer than segment 1. Lateral angles produced, rounded.

Pleon segment 3 : hind margin convex, lower almost straight with a small tooth at the hind angle.

Eyes very large, almost meeting above, elongate-reniform, dark.

Ant. 1 reaching to seg. 5 : 1st joint with a distal tooth below; flagellum more than 4 times as long as peduncle, with 25 calceoliferous joints ; accessory flagellum longer than peduncle, 9-jointed.

Ant. 2. Upper margin of the 2nd joint produced : flagellum about as long as the animal, without calceoli.

Gnathopod 1. Side plates rather deeper than the width at the bottom, front margin concave. Second joint rather wider than the 3rd, which is subequal in length and width to 
the 5th, which is rather longer than the 6th and finely setose on the hind margin; 6 th joint (hand) tapering to the base of the dactylus, sparsely setose. Dactylus bifid, with a comb-like process at the base.

Peræopod 3. Second joint narrowing downwards, the lower two-thirds of the hind margin deeply serrate, with setules between the teeth; 3rd and 4th joints short, 4th wide.

Per. 4. Hind margin of 2nd joint concave below the middle, produced downwards, moderately serrate; 4 th joint narrower than in per. 3.

Per. 5. Hind margin somewhat convex, produced downwards, slightly serrate ; 4th joint narrower than in per. 4.

Uropod 1 reaching the end of uropod 3, peduncle longer than rami, outer ramus slightly the longer.

Ur. 2 not reaching the end of ur. 3, structure as in I. taurus.

Ur. 3. Peduncle subequal to rami, stout, with 4 spines on the distal half of the upper margin; inner ramus rather shorter than outer (fig.), the 2 nd joint almost as long as the 1st, with a curved spine at its base.

Telson cleft three-fourths of its length; ends of the divisions truncate with rounded angles without distal spine or notch (fig).

Length of male $8-9 \mathrm{~mm}$.

This species may be easily recognized by the deeply serrate hind margin of peræeopods 3 and the structure of the telson; in other respects it resembles I. taurus, Costa, as figured by Della Valle.

Genus STEGOCEPHALUS, Boeck.

6. Stegocephalus globosus, sp. n. (Plate 42. fig. 2.)

I. Farquhar: Plankton, $8,250-750$ fms.: two. Desroches: Plankton, $k k, 250 \mathrm{fms}$. several.

Rostrum small. Mesosome very tumid, the first 4 side-plates fully twice as deep as the segments, with sharp lower angles, concealing all the legs except per. $5:$ the 1st is triangular; 2nd and 3rd narrow above and widening below; 4th subequal in width to the preceding 3 united; the margins fit accurately together and, the segments being bent inwards below, form a complete protection to all but the last pair of peræopods. The lower outline forms almost a perfect semicircle.

The hind epimeral angle of pleon segment 3 is bluntly quadrate.

Eyes obscure.

Ant. 1 considerably shorter than ant. 2; peduncle subequal to the 1 st joint of the fagellum; this is 7-jointed, the 1st joint longer than the next 2 unit,d, the last 3 joints long and slender. Accessory flagellum one-fourth as long as the 1st joint of the flagellum, 1-jointed, with a long terminal seta.

Ant. 2 slender, 1st and 3rd joints subequal, 2nd shorter; flagellum 13-jointed, subequal to the peduncle.

Mandibles: both cutting-edges of the left denticulate (fig. 2, M.).

Gnathopod 1. Second joint subequal to the rest of the limb; wrist longer and wider SECOND SERIES.-ZOOLOGY, VOL. XII. 
at the distal end than the simple hand, which tapers to the base of the dactylus and is covered with slender spines (fig. 2, $g n \cdot{ }^{1}$ ).

Gnathopod 2. Second joint subequal to the next 3; wrist subequal in length and width to the hand, which is pyriform and spinous. Dactylus curved, about one-third the length of the palm. Branchial vesicle expanded below.

Peræopods 1 and 2 . Second joint rather wider than 4th and 5th; 6th subequal to 5th, but much narrower (fig. 2, $p p .^{1} \& p p .^{2}$ ).

Per. 3 and 4. Second joint narrow as in per. 1 and 2 , which they resemble. The side plate of per. 4 apparently consists of the 1st joint only as in S. christianiensis ( fide G. O. Sars, Crust. Norway, pl. 70. fig. 2, $p^{5}$ ). 6th joint longer than 4th and 5th united (fig. 2, $p p .4$ ).

Per. 5 reaches to the end of the 4 th joint of per. 4 ; hind margin of 2 nd joint produced downwards and rounded below, smooth. Side plate small, quadrate (fig. $2, p p .5$ ).

Uropod 1 extending beyond 2 and 3 ; peduncle rather longer than the outer ramus, which is blunt at the point; inner ramus shorter than the outer, acute.

Ur. 2 smooth. Inner ramus longer than uropod 3; shorter than the outer, acute; outer blunt.

Ur. 3 smooth. Rami much longer than the peduncle; outer one-third longer than the inner, curved outwards, blunt; inner straight, acute (fig. $2, \mathrm{~T}+u p .^{3}$ ).

Telson wider than long, not quite reaching to the middle of the peduncle of uropod 3 , divided about one-third of its length (fig. $2, \mathrm{~T}+u p \cdot \cdot^{3}$ ).

Length of large specimen $12 \mathrm{~mm}$.

This species is intermediate between Stegocephalus and Stegocephaloides, resembling the former in the even curve of the hind and lower margins of the 4th side plate and the 7 -jointed flagellum of ant. 1, and the latter in the long 1st joint of the flagellum and especially in the narrow 2nd joint of perreopod 4. Although it does not harmonize with either genus as restricted by G. O. Sars, yet it does with Stegocephalus as defined both by Spence Bate (1862) and Boeck (1876). Kröyer's description has been shown to be erroneous. The great depth of the first 4 side plates and the peculiar structure of the uropods are conspicuous characters.

Genus PARANDANIA, Stebbing, 1899.

7. Parandania boecki (Stebbing).

I. Lat. $8^{\circ} 16^{\prime}$ S., long. $51^{\circ} 26^{\prime}$ E.: Plankton, $a a, 900 \mathrm{fms}$. : one. N.W. of Desroches : Plankton, 750-0 fms.: two. Length 8-10 mm.

Agrees well with the 'Challenger' description, except the rami of uropods 1 and 2, which are not spinous, but finely pectinate on the inner margins.

Genus AMPELISCA, Kröyer, 1842.

8. Ampelisca scabripes, A. O. Walker.

II. Wasin, mud, $10 \mathrm{fms}$. One : length $4 \mathrm{~mm}$. 
Genus BYBLIS, Boeck, 1871.

9. Byblis sp.

I. Salomon Atoll, $75 \mathrm{fms}$. Two, immature: length $7 \cdot 5$ and $4 \mathrm{~mm}$.

The above could not be identified with any known species, but are too immature for description. Ant. 1 reaches to the middle of the 3rd joint of the peduncle of ant. 2, of which the 2nd and 3rd joints are subequal. The eyes are obscure. The telson is subquadrate, wider than long, narrowly divided one-fourth of its length, the truncate ends of the divisions spinulose. The hind margin of the 2 nd joint of peræopod 5 is rounded below.

Geuus UROTHÖ̈, Dana, 1852.

10. Jrothoë elegans, Bate.

I. Providence, Plankton, $x$, surface, 8 or 9 males : length $4 \mathrm{~mm}$.

The rose-colour on the bodies is well preserved in formic aldehyde.

Genus LEUCOTHÖ̈, Leach, 1813.

11. Leucothö̈ spinicarpa (Abildgaard).

I. Praslin, weed : 4 small. Amirante, $29 \mathrm{fms}$ : 1 small. S. de Malha, C 1, $150 \mathrm{fms}$, in a Brachiopod : 1 q ovigerous $13 \mathrm{~mm}$.

II. Wasin, mud, $10 \mathrm{fms}$ : 7 , 9 ovig. $7 \cdot 5 \mathrm{~mm}$.

III. Suakim Harbour, sponges 2. Quay wall 1. Other Red Sea localities 5.

12. Leucothö̈ hornelli, A. O. Walker.

III. SS. 'Fayoum.' One : length $5.5 \mathrm{~mm}$.

13. Leucothoë stegoceras, A. O. Walker.

III. Suez Bay. One : length $7 \mathrm{~mm}$.

Genus STENOTHÖ̈, Dana, 1852.

14. Stenothö̈ gallensis, A. O. Walker.

I. Amirante I., dredged, E 14, 36 fms. Four : o $4 \mathrm{~mm}$., \& $3 \mathrm{~mm}$.

II. Zanzibar: many.

III. "From Barnacles I." Five small ovigerous females: length 2-3 mm. SS. 'Fayoum.' Several small.

By an unfortunate error in the Amphipoda of the 'Pearl Fisheries' the 4th peræopod in this species was described as the 3rd, which has the 2nd joint as narrow as in peræopods 1 and 2. This is the more regrettable as it is perhaps the most important difference between this species and S. valida, Dana.

The very small form "from Barnacles" possibly does not belong to this species, the female having a small tooth on the palmar margin near the dactylus as descrihed in S. valida ; unfortunately there is no male. 
Genus COLOMASTIX, Grube, 1861.

15. Colomastix crassimanus (Heller).

III. Suakim Harbour : sponges. One $\delta^{*}$, one $q$.

Length of $\delta 5 \mathrm{~mm}$. , i $4 \mathrm{~mm}$.

This form has hitherto been regarded as the adult male of $C$. pusillus, Grube, because the female agrees with that species. As, however, it has never been recorded from the British area, where C.pusillus is not uncommon, or from the Atlantic coast of France, it is probable that these species (like Seba \&c.) differ only in the males, and I have therefore revived Heller's name. The sexual differences are not confined to gnathopod 2: in the male the joints of all the peræopods are swollen, gnathopod 1 is atrophied (Della Valle) or wanting (Heller); the outer ramus of uropod 1 is peculiarly formed and the inner ramus of uropod 3 very wide. In the above specimen the palm of gnathopod 2 has only two teeth instead of 3 as figured by Heller and Della Valle, but this is a variable character; the 6th joints of the peræopods are pyriform and smooth, and the dactyli very small. C. hamifer, Kossmann, is probably identical with the above, as the palmar teeth of gnathopod 2 are difficult to see.

Genus SYNOPIA, Dana, 1852.

16. Synopia scheeleana, Bovallius.

I. Salomon Atoll, Q, seven. Cargados, g. Amirante, gg. Surface Plankton.

Length 3-4 $\mathrm{mm}$.

Genus STENOPLEURA, Stebbing, 1888.

17. Stenopleura atlantica, Stebbing.

I. N. of Chagos, B, 50 fms.: one. N.E. Gt. Chagos Bank, L, 125 fms.: one young. S. by E. of Farquhar, $8,500-750 \mathrm{fms}$ : : one $\delta^{*}$, length $5 \mathrm{~mm}$. N.W. of Desroches, $k k, 150$ fms. : one. All Plankton.

Peræopod 5 (broken in the 'Challenger' specimen) is much longer than per. 4.

Genus CHAGOSIA, gen. n.

Body rather broad.

Head much deeper than the body, buccal mass and maxillipeds prominent.

Side plates not as deep as the segments.

Antenna 1 much shorter than ant. 2 ; peduncle short; flagellum long and tapering.

Gnathopods with narrow, subchelate, 6th joints; gnath. 2 resembling but longer than 1.

Uropod 3 uniramous.

Telson long, deeply notched, the divisions dehiscent.

This genus, represented by a single specimen, is provisionally placed under Calliopiidæ, with which, so far as can be judged without dissection, it has the most affinity. 
18. Chagosia gardineri, sp. n. (Plate 42. fig. 3.)

I. Between Peros and Salomon Atoll, dredged from $600 \mathrm{fms}$. One female.

Head produced as a short hood covering the base of the antennæ. Eyes rudimentary.

Antenna 1: 1st joint longer than 2nd and 3rd united, widening distally and produced below in a truncate setiferous tooth ; 2nd and 3rd joints subequal, and produced below like the 1st; the 3rd subequal to the 1st joint of the flagellum, which has 30 joints and is about 4 times as long as the peduncle. Accessory flagellum shorter than the 1st joint of the flagellum, 1-jointed, truncate.

Antenna 2: 1st joint short, produced above; 2 nd and 3rd subequal, the 2 nd extending beyond the end of the peduncle of ant. 1 ; flagellum tapering, extremely slender towards the end, about 4 times as long as the peduncle.

Mouth-organs not examined.

Maxillipeds large and prominent; outer plates large, reaching beyond the end of the wide 2nd joint of the palp; 4th joint (nail) almost as long as the 3rd, acute, serrate.

Gnathopods 1 and 2 apparently spring from the base of the maxillipeds; the joints narrow, wrist longer than, and produced beneath almost to the middle of the hand, of which the margins are subparallel; palm obliquely transverse, spinulose: the front margin extends beyond the base of the dactylus; this is longer than the palm and serrate. Side plate of 1 much expanded below, with intra-marginal setæ; that of 2 narrowed and rounded below (fig. $3, g n .^{1} \& g n .^{2}$ ).

Peræopods 1 and 2: second joints narrow, 4th, 5th, and 6th increasing in length successively, with a few scabrous spines and plumose setæ. Dactyli nearly half as long as the 6th joints, with 3 pairs of divergent spines on the concave margin.

Peræopods 3-5: second joints oblong, that of 5th widest; hind margins smooth, rounded below.

Uropods 1 and 2 : rami lanceolate, longer than peduncles, the outer the shorter; both edged with very small submarginal spines; the 1st pair extending beyond the 2nd and almost to the end of the 3rd (fig. 3, ur.).

Uropod 3: ramus lanceolate and acute, 4 times as long as the peduncle, with small submarginal spines and a few longer ones on the inner margin (fig. $3, u r$.).

Telson reaching much beyond the end of the peduncle of uropod 3, deeply emarginato (fig. 3, ur.).

Genus EUSIROIDES, Stebbing, 1888.

19. Eusiroides diplonyx, sp. n. (Plate 43. fig. 4.)

I. Coetivy. Three.

Differs from $E$. monoculoides (Haswell) as follows :-

Pleon segments have no dorsal teeth; the 3rd has the hind and lower margins slightly convex, the hind with 3 small teeth above the subrectangular posterior angle.

Percopods 1 and 2 have a rather long curved spine at the base of and parallel to the dactylus (fig. $4, p p .^{2}$ ): hence the specific name. 
The rami of uropod 3 have long plumose setæ on their inner margins. The telson is cleft beyond the middle; ends of the divisions truncate. Length of female described $6 \mathrm{~mm}$.

Genus EUSIROPSIS, Stebbing, 1897.

20. Eusiropsis riisei, Stebbing.

I. N.W. of Desroches Atoll, Plankton, $m m, 400 \mathrm{fms}$. One: length $11 \mathrm{~mm}$.

The specimen, which was in very perfect condition, was not dissected, but, as far as could be seen, differed from Mr. Stebbing's description only as follows :-

Eyes rather small, round, diameter about equal to the base of ant. 2; ocelli distinct. The preservation of these is probably due to the specimen being in formalin.

Antenna 1. The 2nd joint distally produced above and below in sharp teeth : the flagellum is terminated by a straight simple seta and a longer divergent plumose one. This was broken off in the type.

Genus PARELASMOPUS, Stebbing, 1888.

21. Parelasmopus suluensis (Dana).

I. Praslin Reef. One o .

II. Wasin, mud, $10 \mathrm{fms}$. : fourteen. Wasin, $7 \mathrm{fms}$.: four. Length of female $10 \mathrm{~mm}$. III. "Mud, Crust. and Shells." Several.

In the last of these is a form with the dactylus of gnath. 2 olunt at the point.

Genus MELITA, Leach, 1813-14.

22. Melita fresnelii (Audouin).

I. Amirante, E 14, $36 \mathrm{fms}$ : three. Cargados Carajos, B 25, 22 fms.: four small. i $3.5 \mathrm{~mm}$.

II. Wasin, mud, $10 \mathrm{fms}$. Many : length $5 \mathrm{~mm}$.

III. Suakim Harbour, 5 fms.

Genus CERADOCUS, Costa, 1853.

23. Ceradocus rubro-maculatus (Stimpson).

IJ. Wasin, mud, $10 \mathrm{fms}$. Two: length $6 \mathrm{~mm}$.

Genus MARA, Leach, 1813-14.

24. Mara inaquipes (Costa).

I. Egmont, Lagoon \&c.: four. Praslin, reef \&c.: many. Coetivy : several. Cargados Carajos: a few.

II. Wasin, mud, 10 fms. Three. 
III. Suez Canal entrance: three. Suakim Harbour \&c.

A female with ova from Egmont measured only $4 \mathrm{~mm}$, while one from Praslin measured $7.5 \mathrm{~mm}$.

25. Mara hamigera, Haswell. (Plate 43. fig. 5.)

III. Suez, among coral : one $\delta$, length $7 \mathrm{~mm}$. Khor Dongola : one $\delta$.

Pleon segment 3: hind margin irregularly serrate, the angle acute and produced (fig. 5, $p l .^{3}$ ).

Antenna 2 considerably longer than peduncle of ant. 1 ; flagellum 9 -jointed.

Maxilla 1: inner plate with 3 setæ.

Gnathopod 1: side plate produced anteriorly, acute.

Gnathopod 2: right hand smaller than left: dactylus in both acute (fig. 5, gn.2).

Uropods 1 and 2 reaching a little beyond the end of peduncle of ur. 3.

Otherwise agreeing with Haswell's description.

26. Mara tenella (Dana).

II. Wasin. Three.

To the description in Herdman's 'Pearl Fisheries,' Amphipoda, must be added :-

Uropods. In a young specimen there is only 1 pustero-dorsal tooth instead of 3 , and the tooth on the 2nd segment is minute.

Mandible contorted; joints of palp straight, 2nd the longest.

Maxilla 1 : inner plate with 2 setæe and a setule.

Peræopod 3 reaches a little beyond the 5 th joint of per. $4 ; 2$ nd joint more than twice as long as wide, as long as 4th and 5th united, margins straight, narrowing slightly below, hind margin faintly serrate.

Peræopod 4 rather longer than per. 5 ; 2nd joint wider than that of per. 3 and more distinctly serrate.

Peræopod 5: hind margin of 2nd joint strongly serrate.

Length $7 \mathrm{~mm}$.

All the peræopods are more slender than in $M$. incequipes, and the dactyli of per. I and 2 want the secondary tooth on their inner margin as in the latter species.

$$
\text { Genus ELASMOPUS, Costa, } 18 \check{3} .
$$

27. Elasmopus subcarinatus (Haswell).

I. Cargados, B 25, $22 \mathrm{fms}$. Thirteen: length of $0^{*} 5 \mathrm{~mm}$.

Gnathopod $20^{\circ}$. The wrist and hand have an inflated appearance and are almost naked. It appears to be the form described by Chilton (Proc. Linn. Soc. N.S. Wales, vol. ix. part 4) under Mara petriei, which he identifies with this species; it is probably a condition of immaturity.

28. Elasmopus rapax, Costa.

I. Coetivy : several. Amirante : five. Diego Garcia : three.

II. Zanzibar. Two o , length $7.5 \mathrm{~mm}$.

III. Red Sea (no locality) : a few. Suez, coral : several. Suakim Harbour : one. 
29. Elasmopus insignis, Cherreux.

I. Egmont Reef. Three : length of male $9 \mathrm{~mm}$.

30. Elasmopus serrula, A. O. Walker.

II. Zanzibar, 1901. Many, mostly immature: length of $\delta 7 \mathrm{~mm}$. , $q$ with ova $4 \mathrm{~mm}$.

III. Suez: among Corals. Two.

In addition to the characters given in the description of this species ('Report on Pearl Oyster Fisheries,' 1904: Amphipoda, p. 277, pl. viii. fig. 37), attention may be called to the hairiness of the antennæe and the shortness of the uropods, the telson, viewed sideways in the whole animal, reaching almost to the end of the rami of uropod 3.

It is a question whether this can be considered more than a variety of $E$. rapax.

31. Elasmopus spinidactylus, Chevreux.

Elasmopus spinidactylus, Chevr. Bull. Mus. d'Hist. Nat. 1907, No. 6, p. 412.

” " $\quad$ Mém. Soc. Zool. de France, $20^{\circledR}$ année, 1907, No.4 (juin 1908) p. 486.

I. Egmont and Praslin Reefs. Several.

Female.

Head : lateral lobe flattened in front.

Side plate 1 small, rhomboidal, front nuargin straight; 2 irregularly subquadrate; 5 three times as wide as deep.

Pleon segment 3 : hind margin convex, obscurely serrate; lower margin straight; posterior angle a little produced and upturned, subacute.

Eyes dark, irregularly oval, smaller than diameter of 1st joint of ant. 1.

Antenna 1 reaching 5th segment; flagellum 14-jointed, a little shorter than the peduncle; both very setose. Accessory flagellum 2-jointed.

Ant. 2 barely reaching the end of the peduncle of ant. 1 ; flagellum 7-jointed.

Mouth-organs and maxillipeds normal as in E. rapax.

Gnathopod 1 less than half as large as gnathopod 2; hand longer than wrist, hind margin evenly curved, palm undefined.

Gnathopod 2. Second joint $\frac{2}{3}$ the length of the hand, longer than the next 3 united; wrist short, produced along the front margin of the hand; this is broadly ovate, almost as large as in the male; palm ill-defined, uneven, densely setose. Dactylus reaching the middle of the hind margin. In the male the ovate hand has the outer side of the setose palm, near its proximal end, furnished with a strong recurved tooth, behind, or inside, which is a hollow in which the point of the dactylus fits; a spinous ridge between the tooth and the base of the dactylus.

Peræopods 1 and 2: 1 is stronger than 2; 2nd joint rather narrow, widest near the middle, as long as the next 3 . Dactylus with 3 tooth-like spines, increasing in length distally, on the concave margin : it appears to be hollow near the extreme point, which is terminated by a minute knob.

Peræopod 3 : second joint with the front margin somewhat produced downwards; hind margin obscurely serrate, the posterior angle with a notch just above it. Dactylus as in per. 1 and 2. 
Peræopods 4 and 5 subequal, nearly twice as long as per. $3 ; 4$ with hind margin of 2nd joint slightly concave; in 5 very convex, obscurely serrate. Dactyli powerful, with 5 spines.

Uropod 3 extending beyond 2, the outer ramus twice as long as the inner and subequal to the peduncle, with a cluster of spines on the outer margin.

Telson hardly as long as the peduncle of uropod 3, wider than long, deeply cleft, ends of divisions squarely truncate with rounded angles and 3 long submarginal spines.

Length of male $6 \mathrm{~mm}$.

This species may be easily recognized by the pectinate dactyli of the peræopods and the large gnathopods 2 in the female: also the peculiar form of the hand in gnathopod 2 of the male. In one specimen there is a kind of tumour on both of these.

The above was written before I received the description which $\mathrm{M}$. Chevreux was good enough to send me.

Genus POLYCHERIA, Haswell, 1879.

32. Polycheria atolli, A. O. Walker.

I. Egmont Lagoon. Two of, one $q$ : length $3.5 \mathrm{~mm}$.

II. Wasin, mud, $10 \mathrm{fms}$. Several.

The chief difference between this species and $P$. antarctica (Stebbing) is in the form of the last joint of the palp in maxilla 1, which tapers almost to a point in the latter, while it is squarely truncate in $P$. atolli.

Genus $H Y A L E$, Rathke, 1837 .

33. Hyale macrodactyla, Stebbing.

I. Egmont reef and lagoon: several. Praslin reef: several. Coetivy : a few. Length of female $5 \mathrm{~mm}$.

This is the form described by Chevreux from the Seychelles.

31. Hyale brevipes, Chevreux.

Hyale nilssoni, A. O. Walker, Nat. Hist. Sokotra \&c. 1903, p. 219, pl. xiv. a, figs. 3, and Repor of Pearl Oyster Fisheries, Amphipoda, 1904, p. 238.

III. (No locality.) Several, $\delta$, $q$, and young: length $5 \mathrm{~mm}$.

Genus LEMBOS, Bate.

35. Lembos kergueleni (Stebbing). (Plate 43. fig. 6.)

I. Cargados, B 25, $22 \mathrm{fms}$. Three imperfect.

II. Wasin, mud, $10 \mathrm{fms}$. 'Twelve.

Antenna 1 (wanting in the 'Challenger' specimen) much longer than ant. 2, about as long as two-thirds of the animal, slender; 2nd joint much longer than the 1st and three times as long as the 3rd ; flagellum has more than 21 joints ; accessory flagellum 6-jointed, reaching beyond the end of the 6th joint of the flagellum.

SECOND SERIES.-ZOOLOGY, VOL. XII. 
Gnathopod 10 : hand three times as long as wrist, hind margin longer than palm, which is defined by a blunt, everted tooth, setose on the side; behind this is a large sinus followed by a prominent flat-topped tooth. Dactylus swollen near the middle, not serrate (Fig. also of gn. ${ }^{1}$ o .)

Peræopod 3 short, with a strong distal spine on the 5th joint directed downwards.

Peræopods 4 and 5 : the 2nd joints wider than in the 'Challenger' specimen.

Uropod 3: outer ramus rather shorter and less spinous than the inner.

Length of female (Wasin) $7 \mathrm{~mm}$.

The 'Challenger' specimen was probably immature; the differences indicated above are hardly enough to justify the creation of a new species, though it is quite possible that an adult male from Kerguelen might be perfectly distinct from the above.

36. Lembos podoceroides, A. O. Walker.

III. Mud. Several, mostly small females (some with ova) and young. Length of largest female $5 \mathrm{~mm}$.

The form of the hand of gnathopod 1 varies considerably both in males and females.

37. Lembos leptocheirus, sp. n. (Plate 43. fig. 7.)

II. Wasin, mud, $10 \mathrm{fms.}$ One male.

III. Buoy, canal entrance, Suez : one female. Mud : one female.

Female (Suez).

Head subequal to the first 2 segments united; mesosome segments increasing in length successively; 3rd pleon segment rounded behind; 4th longer than 5th and 6 th united.

Eyes large, dark, wide-oval.

Antenna 1 longer than 2. Accessory flagellum 4-jointed, reaching the middle of the 4th joint of the 11-jointed slender flagellum and longer than the last joint of peduncle.

Ant. 2 stout, 2nd and 3rd joints subequal, the latter longer than the 5-jointed peduncle.

Gnathopod 1: side plate small, rhomboidal. Second joint naked, narrower and longer than the wrist, shorter than the band; 3rd and 4th sparsely setose; wrist half as long as the hand, hind margin densely setose, the setro about as long as the width of the hand, front margin naked; hand widening a little distally, front margin convex, hind crenate and moderately setose; palm convex and obliquely transverse, about one-third of the length of the hind margin, defined by a spine, finely denticulate and shorter than the serrate dactylus (fig. 7, gn..$^{1}$ ). In the male the side plate is produced in front in an acute angle. Second joint stout, naked, a little longer than and about as wide as the wrist; this is as long as the 3rd and 4th joints united and half as long as the hand, the hind margin convex, not produced beyond the hand and densely setose, the setro increasing in length distally : front margin of hand convex, with rows of setæ near distal end, hind margin straight with fascicles of setæ ; palm subequal to the hind margin, oblique, defined by a strong sharp tooth, followed by a deep semicircular sinus and a rather large flat-topped 
prominence. Dactylus as long as the palm, with a cavity in the swollen base into which the prominence fits when closed (fig. $7, g n .{ }^{1}$ ).

Gnathopod 2: side plate subangular in front, scarcely deeper than the segment. Second joint naked, subequal to the next 3 united and to the hand, but wider than the last; 4th joint produced under the 5th, with long setæ on the ovate distal margin; wrist much wider and rather shorter than the long narrow hand, both furnished on the hind surface with long plumose setæ; palm small but distinct, oblique, irregular, and subequal to the serrate finger (fig. $7, g n .^{2}$ ). This limb much resembles gnathopod 2 in Leptocheirus, Zadd.

Peræopods 1 and 2. Second joint rather longer than 4th and 5th united, which are subequal in length and a little narrower than the 2nd; dactylus rather shorter than 6th joint. The whole almost naked.

Peræopod 3 turned up; 2nd joint twice as long as wide, convex in front, slightly convex behind ; 4 th, 5th, and 6 th joints widening distally; 5th joint longer than 4 th.

Peræopod 4 longer than 3 ; 4th joint longer than 5th.

Per. 5 much longer and more slender than 4 ; 4th and 5 th joints subequal; hind margin of 2nd joint fringed with long plumose setæ.

Uropod 3: rami subequal to the peduncle and to each other (fig. 7, ur.).

Telson seen sideways is roof-shaped, divided along its ridge to the base, with an upright spine on each division (fig. 7).

Length $3 \cdot 5 \mathrm{~mm}$.

Though the specimens are from different localities, yet I have no doubt of their specific identity. The peculiar gnathopod 2 and telson are sufficient to distinguish it*.

Genus PHOTIS, Kröyer, 1842.

38. Photis longicaudatus (Bate \& Westw.).

I. Amirante, E 9, 34 fms. : several. Cargados, B 25, 22 fms.: five.

II. Wasin, mud, $10 \mathrm{fms}$. One $q$ ov.

Length of female with ova $3 \mathrm{~mm}$.

Genus EURYSTHEUS, Bate, 1857.

39. Eurystheus zeylanicus $\dagger$ (A. O. Walker).

Gammaropsis zeylanicus, A. O. Walker.

Gammaropsis gardineri, A. O. Walker, young $\delta$.

I. Egmont, breaker zone : one. Praslin Reef. Coetivy. Amirante. Cargados.

Length of of from Coetivy $4 \mathrm{~mm}$.

- Canon A. M. Norman, F.R.S., has called my attention to the resemblance of gnathopod 2 to the same member in his genus Coremapus, from which, however, it differs in the hand of gnathopod 1 in the male.-May 25, 1908.

+ Since this paper was read Mr. Stebbing has published a description (Annals of the S. African Mus. vol. vi. pt. i. p. 86, pl. xl. B) of the male of his Eurystheus (Gammaropsis) atlanticus (Chall. Report, p. 1101, pl. 114). As $E$. zeylanicus appears to be a very variable species, especially as regards the hand of the 2nd gnathopod, I now consider that it ought to be united to $E$. atlanticus (Stebbing).-May 25, 1908. 
40. Eurystheus monuropus, sp. n. (Plate 43. fig. 8.)

I. Praslin Reef. Coetivy. Amirante, 25-34 fms.

II. Wasin, mud, $10 \mathrm{fms} .6$ o.

III. Suakim Harbour, sponges; 5 fms. Two.

Female.

Head: subequal to the first 2 segments; lateral lobe moderately produced, obtusely angular, and almost filled by the large, red, oval eye.

Third pleon segment rounded behind, the lower margin convex; 4th segment depressed in front; 2 stiff dorsal setæ near the hind margin of this and 5th segment.

Ant. 1 and 2 subequal, setose, and rather more than half as long as the whole animal. Ant. 1: 2nd joint the longest; flagellum 10-13-jointed, shorter than the 2nd and 3rd joints of the peduncle united. Accessory flagellum 5-jointed; 4th the longest, 5th minute.

Ant. 2: 2nd and 3rd joints subequal ; flagellum 13-jointed, rather longer than the 3rd and terminated by 2 curved spines.

Mouth-organs normal.

Gnathopod 1 : side plate rather small, produced in an acute but blunted angle, the margins with long setæ. Limb as in E. maculatus (Johnston).

Gnathopod 2 : side plate rather small, rounded below. Second joint stout, rather shorter than the hand; wrist about half as long as the hand, subacutely produced behind, with long setæ; hand subovate, the palm rather longer than the rest of the hind margin, defined by a short blunt tooth, with another tooth between it and the base of the dactylus; front and hind margins setose. Dactylus as long as the palm, not overlapping, but slightly curved (fig. $8, g n .^{2}$ o $)$.

In the male the side plate is narrowed in front with the angle rounded. The second joint stout, about $\frac{2}{3}$ as long as the hand; wrist very short and carpal process very narrow; hand, width to length as $2: 3$, palm subequal to the rest of the hind margin, with 2 very acute teeth situated as in the female. Dactylus moderately stout and curved, the point meeting that of the defining tooth (fig. $8, g n . .^{2}{ }^{\circ}$ ).

Peræopod 3 shorter than gnathopod 2 and upturned; 2nd joint wide-oval; 4th and 5th together subequal to 6th, but twice as wide; 4th longer than 5th, which is subquadrate; these 2 joints and the front margin of the 2 nd are clothed with very long plumose setæ. Dactylus strong, swollen near the base (fig. $8, p p, .^{3} q$ ).

Peræopod 4 like per. 3, but longer in all its parts.

Peræopod 5 much longer and more slender than per. 4 ; dactylus not swollen ai the base.

Uropods 1 and 2 : 1 extending beyond 2 and 2 beyond 3 ; rami in both subequal, spinous, and shorter than the peduncles.

Uropod 3: peduncle short and tumid, subequal to outer ramus, which has 4 or 5 short spines on the upper surface and 3 or 4 rather long unequal setæ at the distal end of the outer margin; inner ramus almost rudimentary, with a small terminal spine (fig. 8, ur.).

Telson wider than long, with a small spine at each angle (fig. 8,ur.).

Length of female with ova $7 \mathrm{~mm}$. 
Easily recognizable by the peculiar structure of uropod 3, which, under a low power, appears to be uniramous, hence the specific name; also by the powerful gnathopod 2 in the female. In the former character this species approaches the genus Photis and will not fit into the Synopsis of the Photidæ (Tierreich, Amph. Gam. p. 603), but its welldeveloped accessory flagellum and general form are nearer to Eurystheus. E. hirsutus, Giles, appears to be very near this species, but there is no mention of the inequality of the rami of uropod 3 in that author's description.

Genus LEPTOCHEIRUS, Zaddach, 1844.

41. Leptocheirus pilosus, Zaddach.

1. Protomedeia hirsutimana, Bate?, p. 402.

2. Protomedeia pilosa (Zadd.), p. 417 in desc. of plate. $\}$ pl. 10. fig. 2.

3. Protomedeia pectinata, Norman, Rep. Brit. Assoc. 1869, p. 283.

3 a. Leptocheirus pilosus, Della Valle, Gamm. des Golfes Neap. p. 427, pl. 12. figs. 1-14.

4. Leptocheirus pilosus, A. O. Walker, Trans. Liverpool Biol. Soc. vol. ix. 1895, p. 310.

5. Leptocheirus pilosus, Chevreux, Camp. de l'Hirondelle, Amph. p. 90, pl. 11. fig. 2 (1900).

6. Leptocheirus pectinatus, Stebbing, Tierreich, p. 629 (1906).

II. Wasin, mud, $10 \mathrm{fms}$. Two: length $3 \mathrm{~mm}$.

The above agree with Della Valle's figures, except that the anterior angle of side plate is less produced and the last 2 pairs of peræopods are stouter than figured. In both these points the specimens resemble those taken at Port Erin, I. of Man.

I still hold by the opinion given in 1895 (4 supra) and shared by Mons. Chevreux (5 supra) that L. pectinatus, Norman, is identical with $L$. pilosus, Zadd.; nor can I find sufficient justification in the prolongation of the anterior angle of side plate 1 for making a separate species ( $L$. della vallei, Stebb.) of the form described and figured by Della Valle as L. pilosus. In the Wasin and I. of Man forms the angle of the side plate appears to be about $45^{\circ}$.

Genus CHEVALIA, A. O. Walker, 1904.

42. Chevalia avicula, A. O. Walker.

I. S. de Malha, C 16, 26 fms. One male: length 6.5 mm. Cargados, B 25, 22 fms. Two.

The male specimen differs from those from Ceylon in having the wrist in gnathopod 2 shorter in proportion to the hand and the front margin less rounded. As it is larger it may be an older male than the Cinghalese examples.

Genus $A M P H I T H O \ddot{E}$, Leach, 1813.

43. Amphithoë intermedia, A. O. Walker.

I. Praslin reef. One.

II. Zanzibar. Several.

III. Suez : several. Khor Dongola: six.

Length of female with ova $8 \mathrm{~mm}$. 
44. Amphithoë lobata, sp. n. (Plate 43. fig. 9.)

II. Wasin, 7 fms. Two.

Male.

Body stout; pleon segment 3 irregularly rounded behind.

Side plates about as deep as the segments : 1 produced in front to a blunted acute angle; 2 oblong, deeper than wide, angles rounded.

Head nearly as long as the first 2 segments. Eye small, almost round, red.

Ant. 1 (wanting in $\sigma^{*}$ ) in of more than half as long as the body; 1st joint rather longer than the 2nd, which is 3 times as long as the 3rd ; flagellum slender, 28-jointed, the joints lengthening distally.

Ant. 2 shorter (in $q$ ) than ant. 1; 2nd joint rather longer than 3rd; flagellum longer than peduncle, many-jointed, setose.

Mandibles have a 6-7-toothed tertiary cutting-edge, the teeth much larger than those of the primary and secondary, above the molar process; 2nd and 3rd joints of palp subequal, the terminal setæ of the latter spinulose (fig. 9, M.).

Maxilla 1: inner plate with one seta.

Gnathopod 1. Second joint rather longer and narrower than the hand, distal end in front furnished with a crenate border and lobe, both spiniferous ; the lobe reaches almost to the end of the 3rd joint, which has a similar lobe without spines; the 4 th joint is produced behind in a blunted setose point extending as far as the broader carpal process ; wrist shorter than the hand, process prominent, setose, front margin with 3 short spines; hand about twice as long as wide, palm oblique, shorter than hind margin, palmar angle rounded and succeeded by a shallow sinus. Dactylus as long as the palm, inner edge closely serrulate and spinulose (fig. $9, g n .^{1} \sigma^{*}$ ).

In the female (perhaps immature) the 4th joint is not produced behind, and the palm of the hand is evenly convex and defined only by a spine.

Gnathopod 2 subequal to and resembling 1 both in $\delta$ and $q:$ in the $\delta$ the hand has more and longer setæ, especially on the front margin.

Peræopods 1 and 2: second joint more than twice as wide as 4 th.

Peræopod 3 stout; 2 nd joint wider near the top than deep, front margin with 5 spines.

Peræopod 5 : 2nd joint ovate, hind margin slightly serrate.

All the peræopods are very sparsely setose.

Uropod 1: peduncle longer than rami, of which the outer is the longer.

Uropod 2: rami subequal, extending a little beyond uropod 1.

Uropod 3 as in $\boldsymbol{A}$. rubricata (Mont.).

Telson has 4 or 5 stiff upright setæ in a row, the largest near the distal end.

Length $7 \mathrm{~mm}$.

The chitinous lobes on the 2nd and 3rd joints of the gnathopods and the peculiar accessory cutting-edge of the mandibles characterize this species. 
Genus PARAGRUBIA, Chevreux, 1901.

45. Paragrubia vorax, Chevreux.

I. Coetivy. Two males, one female. Length of large male $10.5 \mathrm{~mm}$.

In the smaller male dissected the inner lobe of maxilla 1, which Chevreux was unable to find, is present, but very small; it has one seta. In both males gnathopod 2 is smaller than gnathopod 1 as in Chevreux's specimens, but, unlike them, has a concave palm. The superficial resemblance of the male Paragrubia vorax to the female Lembos kergueleni is so great that they can only be distinguished by the difference in the form of the mandibular palp and uropod 3.

Genus BRUZELIELLA, Norman, 1905.

46. Bruzeliella falcata (Montagu).

Podocerus falcatus (Montagu), auctorum. Bruzeliella falcata (Montagu), Norman.

Jassa pulchella, Leach; Stebbing, Tierreich, p. 654.

II. Zanzibar. Three males, several females, and young.

Length of male $3.5 \mathrm{~mm}$.

Genus ERICTHONIUS, Milne-Edwards, 1830.

47. Ericthonius brasiliensis (Dana).

I. Amirante, E 11, 25-80 fms. Three.

II. Zanzibar. Two males, a few females, and young. Length of female $5 \mathrm{~mm}$.

III. Suez. Several, mostly females. Length of male $4.5 \mathrm{~mm}$.

Genus COROPHIUM, Latreille, 1806.

48. Corophium bonnellii, M.-Edwards.

III. Suez. Many, mostly females. From Barnacles, R. Three males, two females. Length of female $4 \mathrm{~mm}$. Male $3 \mathrm{~mm}$.

Genus PODOCERUS, Leach, 1813.

(= Platophium, auctorum.)

49. Podocerus synaptocheir (A. O. Walker).

II. Zanzibar. One adult and one young male; several females with ova, length $3 \mathrm{~mm}$., male $4.5 \mathrm{~mm}$.

III. Suez, buoy, canal entrance; many. 
Genus CAPRELLA, Lamark, 1818.

50. Caprella simia, Mayer.

Caprella simia, Mayer, 'Siboga' Exped., Caprellidæ, p. 123, pl. 5. fig. 31 \& pl. 8. fig. 25.

I. Lat. $18^{\circ} 09^{\prime}$ S., long. $58^{\circ} 26^{\prime}$ E.: Plankton, $e$, surface. One male, length $15 \mathrm{~mm}$.

EXPLANATION OF THE PLATES.

Plate 42.

Fig. 2. Stegocephalus globosus, sp. $\mathrm{n}$.

Fig. 3. Chagosia gardineri, sp. n.

Plate 43.

Fig. 1. Ichnopus serricrus, sp. n.

Fig. 4. Eusiroides diplonyx, sp. n.

Fig. 5. Mara hamigera, Haswell.

Fig. 6. Lembos kergueleni (Stebbing).

Fig. 7. Lembos leptocheirus, sp. $\mathrm{n}$.

Fig. 8. Eurystheus monuropus, sp. n.

Fig. 9. Amphithoë lobata, sp. n. 


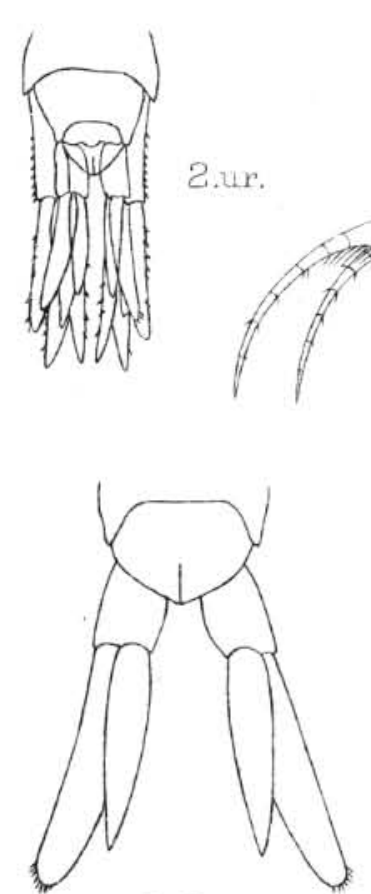

2. T+up.

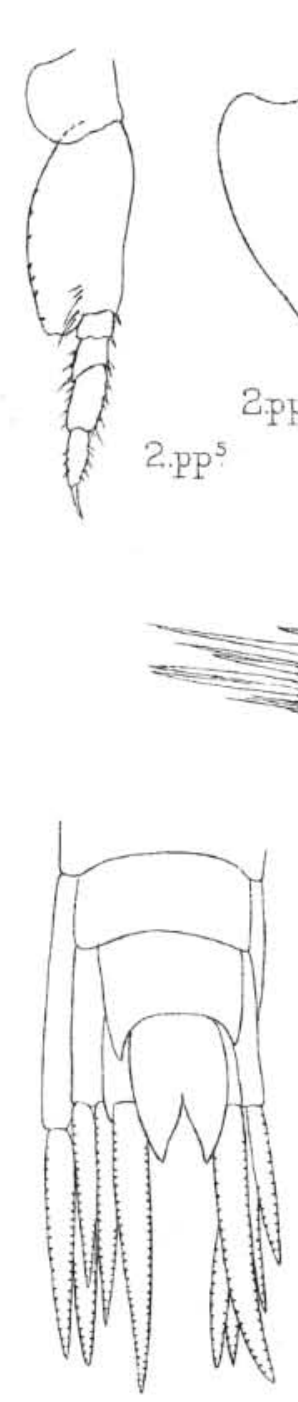

3.ur.

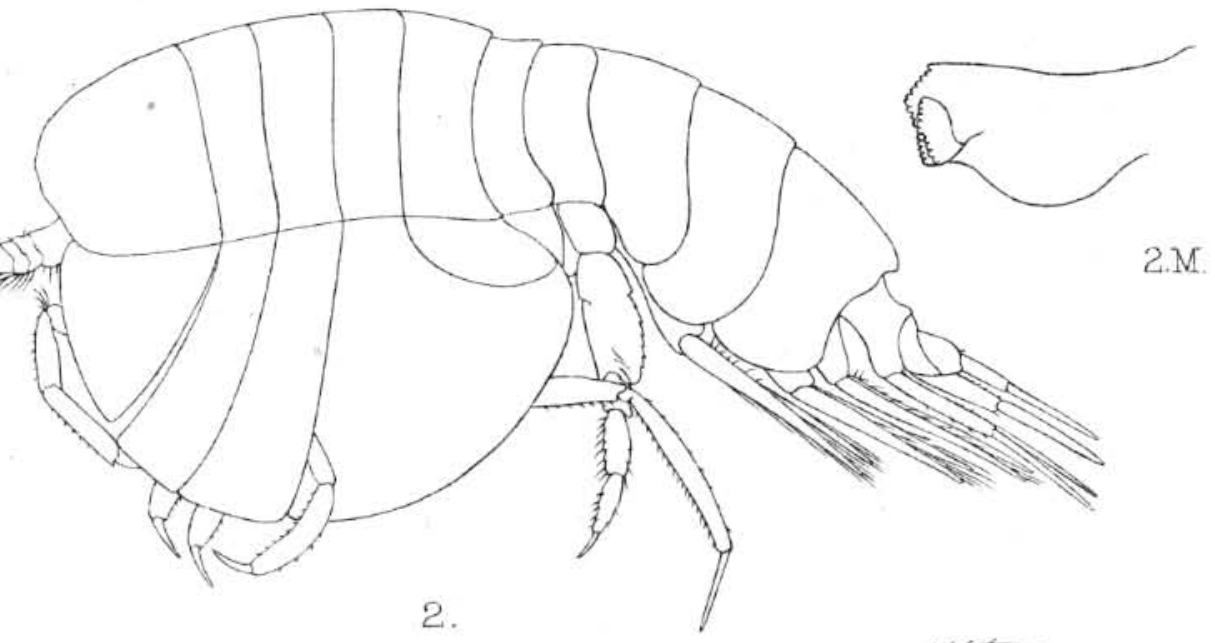

2.M

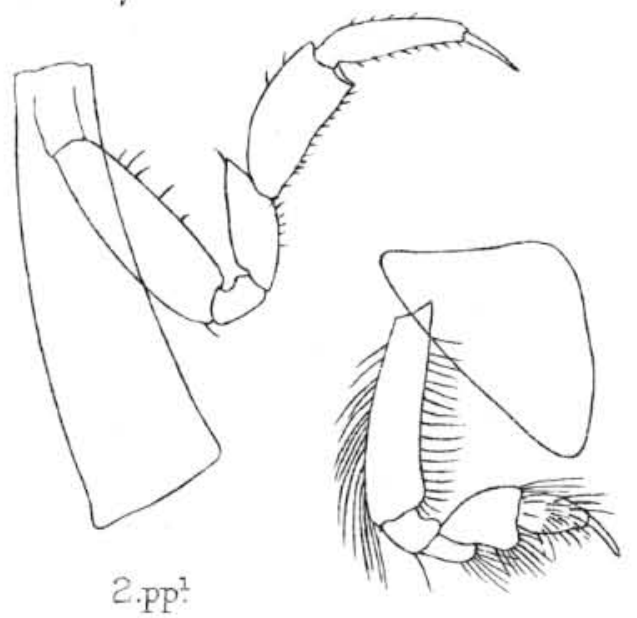

2. $\xi n^{1}$
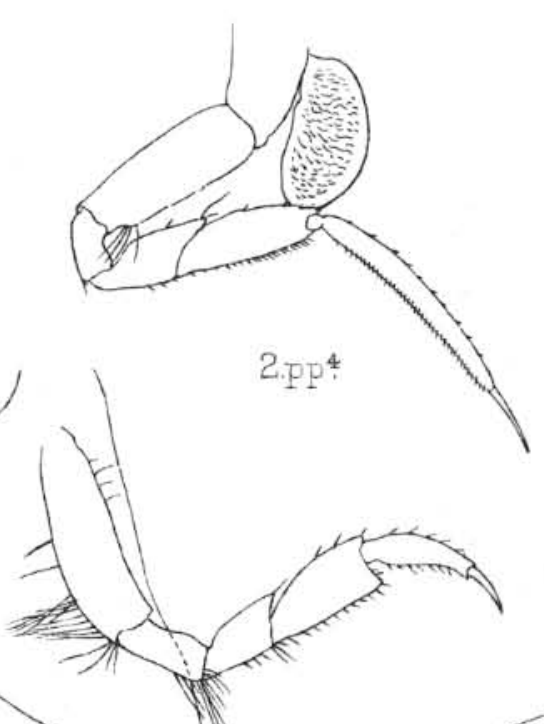

2.pp? 
(WAIKFR)
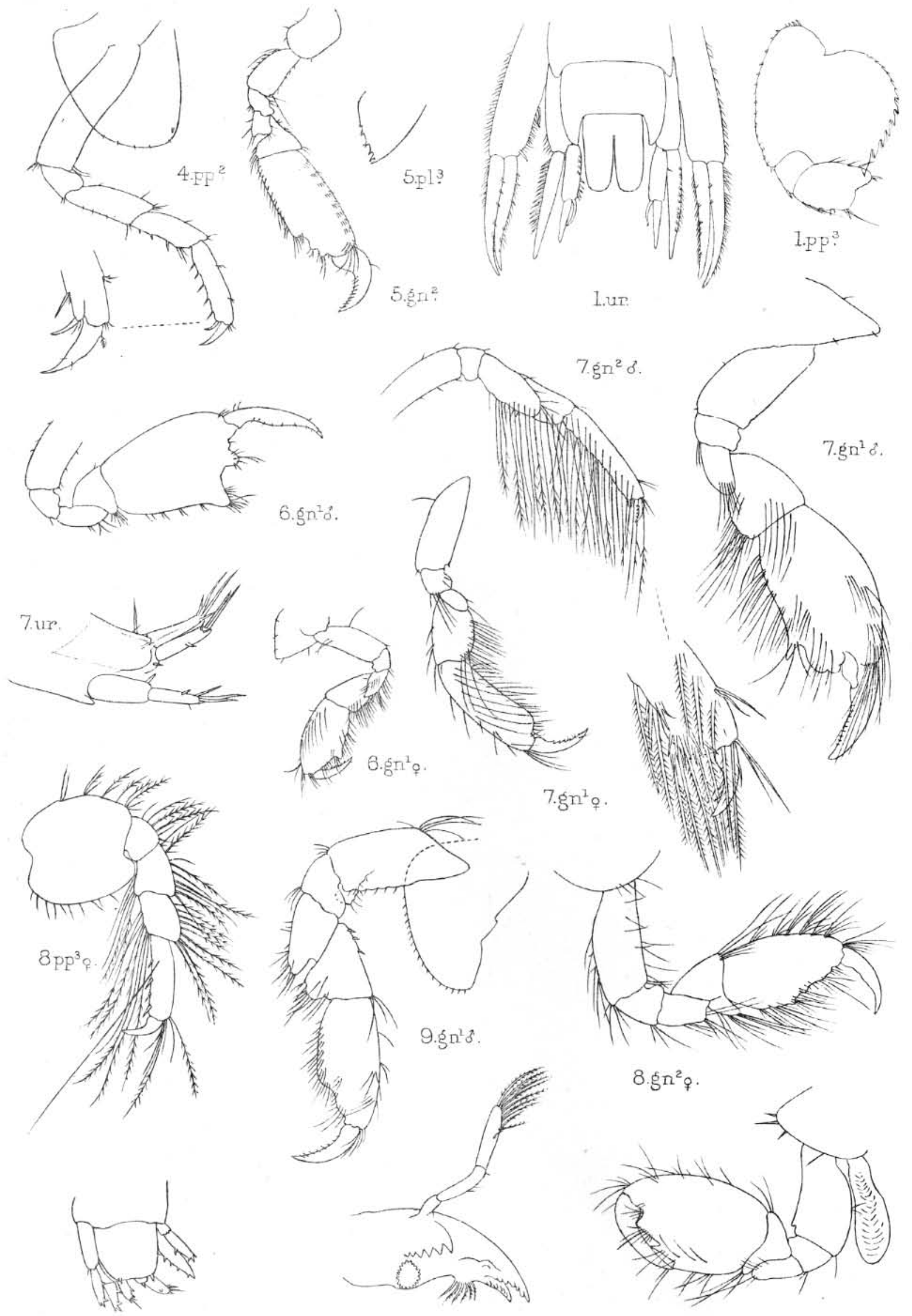

8.ur.

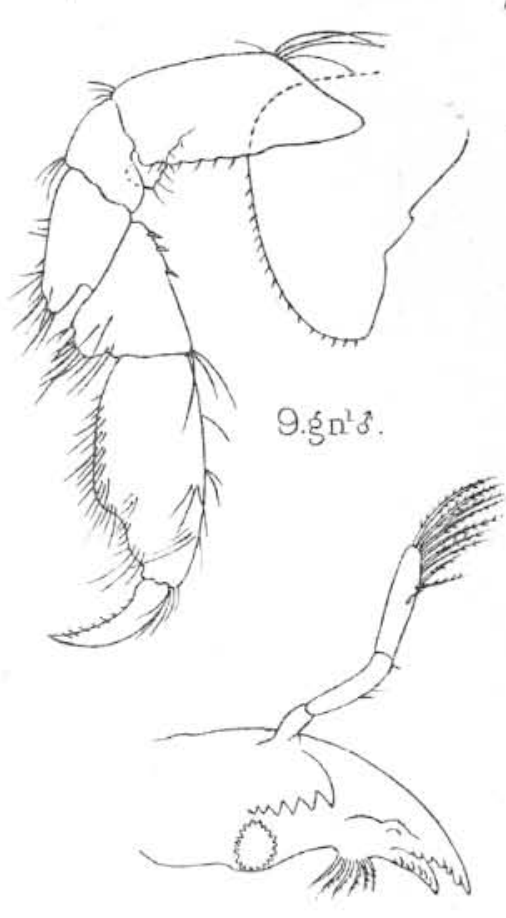

O.M.

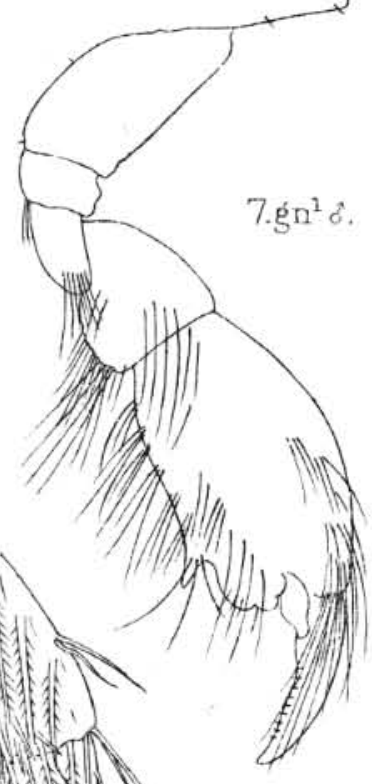

$$
\text { 7. } \mathrm{gn}^{1} \text { \%. }
$$
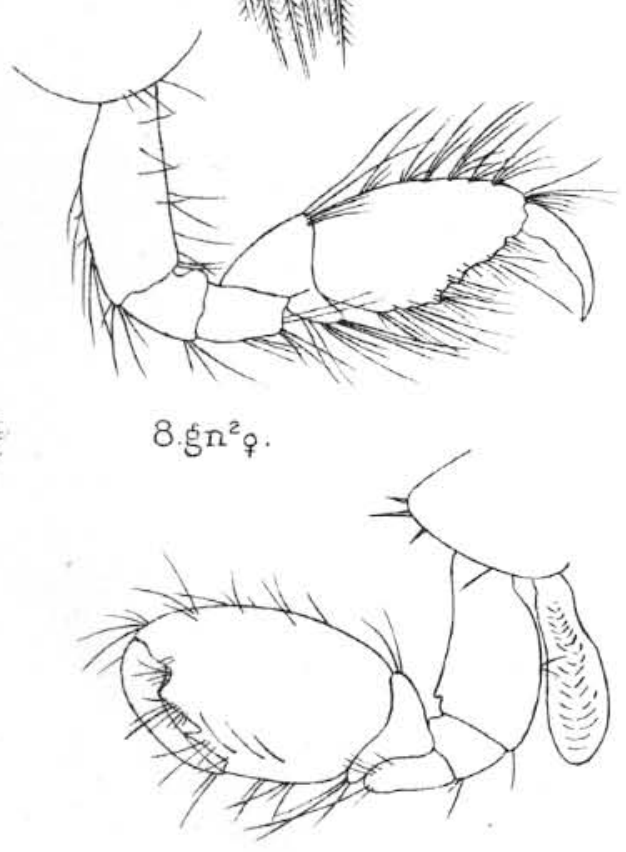

8. $g n^{2} 8$. 